\title{
Isolation and morphotyping of Acanthamoeba spp. and Vermamoeba spp. from hospital air- conditioning systems
}

\section{Hastane klima sistemlerinden Acanthamoeba ve Vermamoeba türlerinin izolasyonu ve morfotiplendirilmesi}

\author{
Semra ÖZÇELIIIK, Önder YÜNLÜ, Necati ÖZPINAR
}

Cumhurivet University, Faculty of Medicine, Department of Parasitology, Sivas

Corresponding author: Necati ÖZPINAR, Department of Parasitology, Cumhuriyet University, Sivas, Turkey

E-mail: necatiozpinar@gmail.com

Received/Accepted: June 27, 2016 / January 25, 2017

Conflict of interest: There is not a conflict of interest.

\section{SUMMARY}

Objective: The aim of the study was to investigate the presence of free-living amoebae (FLA) such as Acanthamoeba and Vermamoeba in air conditioning systems of Cumhuriyet University Research and Application Hospital (CURAH). Method: For this purpose, twenty-four dust samples were collected using sterile cotton swaps from grilles and filters of five different unit air-conditioners of CURAH located in Sivas, Turkey. Samples were transferred in a sterile tubes to the laboratory and spread onto non-nutrient agar (NNA) plates with a lawn of inactive Escherichia coli. Culture plates were incubated at $30^{\circ} \mathrm{C}$. FLA genera was identified according to morphotyping keys.

Results: FLA were found in 14 (58.3\%) of examined 24 air-conditioner. Ten (41.6\%)were identified as Vermamoeba spp, 4 (16.7\%) as Acanthamoeba spp., after microscobic examination.

Conclusions: These findings should alert us on the risk of Acanthamoeba and Vermamoeba infections. In addition, these amoebas could be host for bacteria, fungi and viruses and indirectly become agents of transmission for these pathogens. For decrease the risk both Acanthamoeba and their endosymbionts, regularly cleaning of air-conditioner filters and grilles using effective disinfectants are essential.

Keywords: Acanthamoeba spp., Vermamoeba spp., Air-conditioning system

\section{ÖZET}

Amaç: Çalışmada, Cumhuriyet Üniversitesi Araştırma ve Uygulama Hastanesi klimalarında Acanthamoeba ve Vermamoeba gibi serbest yaşayan amiplerin (SYA) varlığının araştırılması amaçlanmıştır.

Yöntem: $\mathrm{Bu}$ amaçla, hastanenin beş farklı ünitesinden toplam 24 klimanın 1zgara ve filtre kısımlarından steril eküvyonlarla sürüntü örnekleri alınmıştır. Alınan sürüntü örnekleri steril tüplerde laboratuara getirilmiş ve üzerine inaktive edilmiş E.coli içeren Besleyici Değeri olmayan Agar plaklarına yayılmıştır. Ekim yapılan plaklar $30^{\circ} \mathrm{C}$ de inkübe edilmiştir. Üreme olan plaklardan pasajlar yapılmıştır. Saptanan amipler morfotiplendirme anahtarları kullanılarak cins düzeyinde tanımlanmıştır.

Bulgular: İncelenen 24 klima örneğinin 14’ünde (\%58.3) SYA saptanmıştır. Bunlardan 10’unda (\%41.6) Vermamoeba spp, 4’ünde (\%16.7) Acanthamoeba spp. tanımlanmıştır.

Sonuç: $\mathrm{Bu}$ bulgular klima sistemlerinde potansiyel patojen SYA ler açısından dikkatli olunması gerektiğini göstermektedir. Ayrıca, bu amipler içlerinde patojen bakteri, mantar ve virusları taşıyabilmektedir. Hem SYA hem de içlerinde taşıyabilecekleri endosimbiyontlarıyla ilgili riskleri azaltmak için havalandırma sistemleri düzenli olarak etkili dezenfektenlarla temizlenmelidir.

Anahtar Sözcükler: Acanthamoeba spp., Vermamoeba spp, Klima sistemleri 


\section{INTRODUCTION}

Free-living amoebae (FLA) such as Acanthamoeba, Naegleria, Balamuthia and Sappinia have been isolated from many different environment and clinical samples: soil, air, fresh water, tap water, ear, lung secretions, nasopharyngeal mucosa samples ${ }^{1-4}$. They have been associated with infections of the central nervous system in humans ${ }^{5-7}$. Acanthamoeba and Naegleria are the most common FLA genuses ${ }^{2}$. But Balamuthia and Sappinia are less common causes of clinically significant infections. Naegleria fowleri is the only species of Naegleria that causes the disease was called primary amoebic meningoencephalitis (PAM $)^{6}$. Acanthamoeba infections involves the skin and central nervous system in immunosuppressed patients. They are causative agents of granulomatous amoebic ensephalitis (GAE). Also occasionally involves the cornea in relatively healty patients by causing Acanthamoeba Keratitis (AK). Another genus is Vermamoeba: Vermamoeba vermiformis is potential pathogen in humans ${ }^{8}$. Bacterial pathogens such as Legionella pneumophila, Pseudomonas spp., Staphylococcus spp, Proteus spp. and some Mycobacteria spp. are taken up by FLA without undergoing digestion. These bacteria multiply within FLA thus increasing the probability of causing infections in humans ${ }^{4}$.

The air-conditioner is essential in living indoor area for comfort and as a symbol of development and modern lifestyles. On the other hand, air conditining systems has been shown to be the source of air-born bacterial, viral etc. diseases. Therefore, in the present study, we analysed dust samples obtained from air-conditioning systems of Cumhuriyet University Research and Application Hospital (CURAH).

\section{METHODS}

In the study, twenty-four dust samples were collected using sterile cotton swabs from grilles and filters of five different unit air-conditioners of CURAH located in Sivas, Turkey.

\section{Collection of air-conditioner swab samples}

Samples (in total N=24) were collected from airconditioning systems between June-September 2011. Swab samples were obtained from the inner surface, grills and filters of air-conditioners using sterile cotton swabs. Samples were taken from an area of approximately $50 \mathrm{~cm}^{2}$. Then these swabs were placed in the sterile plastic tubes containing $2 \mathrm{~mL}$ of sterile buffer solution. The samples were stay overnight at room temperature in the parasitology laboratory. Four dust samples were obtained from air conditioners of Blood centre, 3 dust samples were from Haematology laboratory, 8 dust samples were from Biochemistry laboratuary, 9 dust samples were from Radiology units in September 2011.

\section{The incubation of samples and culture}

For the culture of samples non-nutrient agar (NNA) was used. NNA was prepared with page ameba saline (PAS) $\left(2.5 \mathrm{mM} \mathrm{NaCl}, 1 \mathrm{mM} \mathrm{KH}_{2} \mathrm{PO}_{4}, 0.5 \mathrm{mM}\right.$ $\mathrm{Na}_{2} \mathrm{HPO}_{4}, \quad 40 \mu \mathrm{M} \quad \mathrm{CaCl}_{2}-6 \mathrm{H}_{2} \mathrm{O}$ and $20 \mu \mathrm{M}$ $\mathrm{MgSO}_{2} .7 \mathrm{H}_{2} \mathrm{O}$ ). Agar was dissolved in PAS (1.5\%), autoclaved and dispensed onto sterile plates. The dust samples were stayed overnight at room temperature. The day after sampling day, the tubes were santrifuged at $1000 \mathrm{rpm}$ for ten minutes. To isolate FLA, pellet were placed on NNA plates containing a layer of inactivated Escherichia coli as a food source. The plates were incubated at $30^{\circ} \mathrm{C}$.

\section{Isolation and passages}

After two days of incubation, the plates were examined for the detection of trofozoites or cysts of FLA. Plates were examined daily. Once growth was spotted approximately $1 \mathrm{~cm}^{2}$ of agar containing the FLA trophozoites or/and cysts was taken from the grown culture and placed at new NNA plates with a lawn of heat-killed E.coli. Detected FLA were maintained by serial passages in this medium.

\section{Identification}

For identification of FLA, the movement and structral properties of amoebas were analysed. The cyst and trophozoite morphology of FLA were examined using light microscope and the genera was identified according to morphotyping keys ${ }^{9-12}$.

\section{Statistic analysis}

The data obtained from this study using SPSS (Ver: 22) I installed the program. Khan-square test was used to evaluate the data. Groups Fisher's exact test was used for differences between and $p<0.05$ was considered significant.

\section{RESULTS}

FLA were recovered from $14(58.3 \%)$ out of 24 swab samples. Acanthamoeba spp. were identified in $4(16.7 \%)$, and Vermamoeba spp. in $10(41.6 \%)$ with morphotyping (Figure 1,2). The units of taken the dust samples and the distribution of obtained FLA were given Table 1. There was no difference between the groups performed the statistical analysis. 
Acanthamoeba cyst forms were typical with a starlike shape and very easy to differentiate as Group I and II. But Vermamoeba cyst forms was more similar on NNA.

Identification of Acanthamoeba trofozoites at the genus level is relatively easy due to the presence of spiny surface projections, called acanthapodia, on trophozites. But, using only morphological criteria, identification of these amoebae at the species level has been difficult. The genus of Acanthamoeba have been placed into three morphological groups (I,II and III) based on cyst size and shape $\mathrm{e}^{9-12}$.
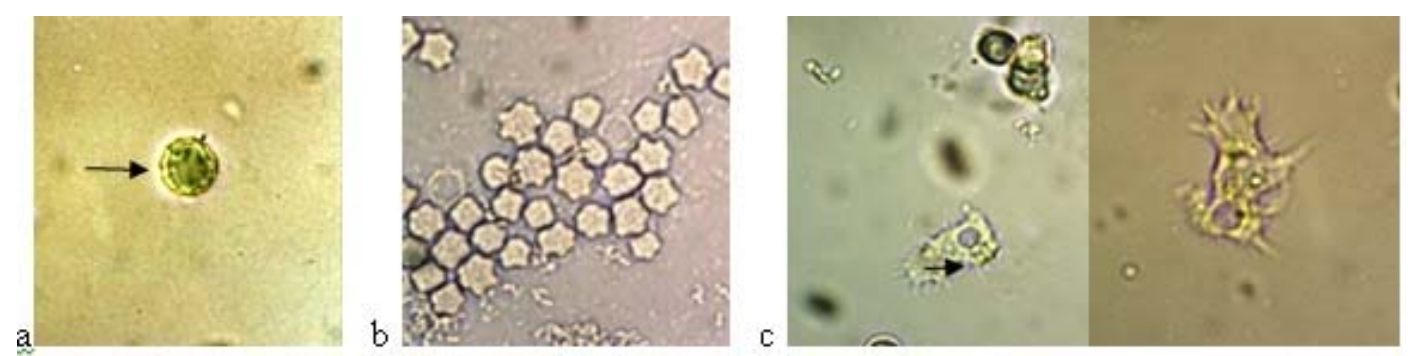

Figure 1. Acanthamoeba spp. cyts obtained from samples, a. Cyst in saline(40x),b. Cyts on NNA (40x).c. Acanthamoeba trophozoites in saline(40x)
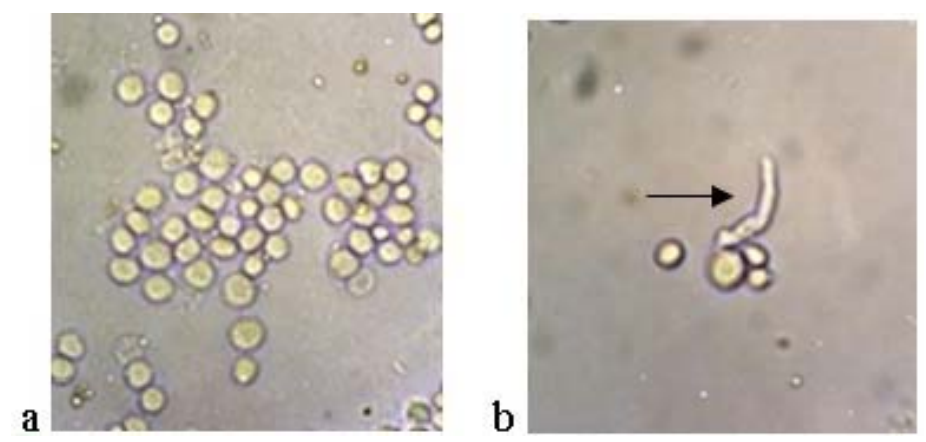

Figure 2. Vermamoeba spp. a.Cysts on NNA, b.Trophozoites in saline (40x)

Table 1. The source of air-conditioner samples and identified FLA

\begin{tabular}{|c|c|c|c|c|c|c|c|c|}
\hline & \multicolumn{4}{|c|}{ FLA } & \multicolumn{2}{|c|}{ Acanthamoeba } & \multicolumn{2}{|c|}{ Vermamoeba } \\
\hline Source & $\begin{array}{l}(+) \\
\text { No }\end{array}$ & $\%$ & $\begin{array}{l}(-) \\
\text { No }\end{array}$ & $\%$ & No & $\%$ & No & $\%$ \\
\hline Unit 1 & 3 & 12.5 & 1 & 4.17 & 1 & $4.17 \mathrm{a}$ & 2 & 8.33a \\
\hline Unit 2 & 2 & 8.3 & 1 & 4.17 & 1 & $4.17 \mathrm{a}$ & 1 & $4.17 \mathrm{a}$ \\
\hline Unit 3 & 4 & 16.7 & 4 & 16.7 & 1 & $4.17 \mathrm{a}$ & 3 & $12.5 \mathrm{a}$ \\
\hline Unit 4 & 5 & 20.8 & 4 & 16.7 & 1 & $4.17 \mathrm{a}$ & 4 & $16.7 \mathrm{a}$ \\
\hline Total & 14 & 58.3 & 10 & 41.6 & 4 & $16.67 a$ & 10 & $41.66 \mathrm{a}$ \\
\hline
\end{tabular}

a: No differences were found between groups, Ffisher's exact test, 2-sided

The genus of Vermamoeba trophozoite is monopodial; body subcylindirical with circular cross-sections; no lateral wrinkles, never has adhesive uroid ${ }^{9}$. They had a hyaline anterior region almost always longer than broad. Cyst forms of these amoebae genus have smooth-walled, which were spherical or ovoid. The median of cyst diameter was $8-10 \mu \mathrm{m}$. Cyst walls were mostly homogeneous ${ }^{10}$. 


\section{DISCUSSION}

Free-living amoebae, ubiquitous and widely distributed protozoa, feed on bacteria, algae, fungi, and small organic particles and are adaptable to their environment. FLA have been isolated from samples obtained from environmental materials such as pools, lakes, thermal springs, domestic water supplies, soil, air, dust, air-conditioning units $^{1-7}$. To our knowledge the presence of FLA in the environment does not mean a risk factor for illness. However, many species of Acanthamoeba are potentially pathogenic for animals and for humans. The prevalence of FLA have been reported to be $30 \%$ from environmental waters and tap water systems in Sivas ${ }^{13,14}$. Also in the other study from Sivas isolated Acanthamoeba spp. obtained from tap water systems as pathogen T4 type have been reported ${ }^{13,14}$. The prevalence of FLA have been reported to be between $23 \%$ and $89 \%$ from water systems in the world ${ }^{1}$. Legionella bacteria present within FLA can survive and become resistant to inappropriate environmental conditions. Moreover, FLA play a major role in $L$. pneumophila transmission. By Burak and Zeybek, the presence of L.pneumophila and FLA have been examined in water and swab samples obtained from shower heads in 61 houses in İstanbul. L.pneumophila have been isolated from $21.3 \%$ of houses examined and FLA from $31 \%$. But no significant correlation have been found between the presence of L.pneumophila and FLA ${ }^{15}$.

In Iran 13 strains have been isolated from dust samples and classified at the genotype level. Results revealed the presence of T4, T5 and T11 genotypes within these samples ${ }^{16}$. During the harmattan in Nigeria, the presence of FLA was reported obtained from air and isolated a total of 38 strains of FLA by Lawande ${ }^{17}, 21$ of the genus Acanthamoeba, eight Naegleria, four Schizopyrenus, three Didascalus and two Tetramitus. Three pathogenic species, $A$. culbertsoni, $N$. fowleri and A. rhysodes, were also reported $^{17}$. El Sibae reported presence of Acanthamoeba polyphagia in the cooling towers of the air conditioning systems ${ }^{18}$. According to these researhers FLA may be source for numerous outbreaks of air-born diseases such as the aspergillosis, Legionnaires' disease and Severe Acute Respiratory Syndrom caused by SARS virus.

In Malaysia, Chan et al. have been isolated $A$. castellani, A.culbertsoni, A.griffini, A.hatchetti and A.polyphaga from air-conditioners. They have detected Acanthamoeba spp in 20 out of 87 dust samples. All Acanthamoeba spp. samples have been found pathogen T4 type ${ }^{19}$.

Astorga et al. have also been isolated FLA from airconditioning units from Chile. They have collected water and air samples from air-conditioning systems and checked for the presence of Acanthamoeba spp. Positive samples have been further classified at the genotype level after sequencing the highly variable diagnostic fragment 3 (DF3) region of the $18 \mathrm{~S}$ rRNA gene ${ }^{20}$.

\section{CONCLUSIONS}

In this study the presence of FLA in air condition system of CURAH was investigated. Twenty-four dust samples were collected using sterile cotton swaps from grilles and filters of five different unit air-conditioners of CURAH located in Sivas, Turkey. FLA were found in $14(58.3 \%)$ of examined 24 air-conditioner. Ten $(41.6 \%)$ were identified as Vermamoeba spp, $4(16.7 \%)$ as Acanthamoeba spp., after culture and microscobic examination. This is the first time Acanthamoeba and Vermamoeba spp. have been isolated from airconditioning systems in Turkey.

The public health importance of FLA is explaned in two ways. First, FLA are themselves opportunistic pathogens in humans. Second, FLA serve as reservoirs for pathogenic bacteria and virus. So, the filters of air-conditoner must be clean frequently. Overall, the widespread distribution of potentially pathogenic FLA in the studied source demands more awareness within the health professionals in Turkey as this pathogen is emerging as a risk for human health worldwide.

\section{REFERENCES}

1. Visvesvara GS, Stehr-Green JK. Epidemiology of free-living ameba infection J.Protozool 1990; 37: 25-33.

2. Szenasi Z, Endo T, Yagita K, Nagy E. Isolation, identification and increasing importance of free-living amoebae causing human disease. J Med Microbiol 1998; 47: 5-16.

3. Armstrong M. The pathogenesis of human Acanthamoeba infection. Infect Dis Rev 2000; 2: 65-73.

4. Cabral FM, Cabral G. Acanthamoeba spp. as agents of disease in humans. Clinical Microbiol Rev 2003; 273-307.

5. Khan NA. Pathogenicity, morphology, and differentiation of Acanthamoeba. Current Microbiol 2001; 43: 391-395. 
6. Cabral FM. Biology of Naegleria spp. Microbiol Rev 1988; 52: 114-33.

7. Sayg 1 G, Polat ZA. Free-living amebae and the parasitosies they cause. Cumhuriyet Medical Journal 2003; 25: 140-9. Available from: http://eskidergi.cumhuriyet.edu.tr/makale/450. pdf

8. Tyson JY, Vargas P, Cianciotto NP. The novel Legionella pneumophila type II secretion substrate NttC contributes to infection of amoebae Vermamoeba vermiformis and Willaertia magna. Microbiology. 2014 Sep 24. pii: mic.0.082750-0. http://dx. doi.org10. 1099/mic.0.082750-0.

9. Smirnov AV, Goodkov AV. An illustrated list of basic morphotypes of Gymnamoebia (Rhizopoda, Lobosea), Protistology 1999; 1:2029.

10. Dykova I, Pindova Z, Fiala I, Dvorakova H, Machackova B. Fish-isolated strains of Vermamoeba vermiformis Page,1967: morphology, phylogeny and molecular diagnosis of the species in tissue lesions. Folia Parasitologica 2005; 52: 295-303.

11. De Jonckheere JF. Molecular definition and the ubiquity of species in the genus Naegleria. Protist 2004; 155: 89-103.

12. Page FC. An Illustrated Key to Freshwater and Soil Amoebae. 1976. Freshwater Biol. Ass., Ambleside.

13. Özçelik S, Coşkun KA, Yünlü Ö, Alim A, Malatyalı E. The prevalence, isolation and morfotyping of potentially pathogenic freeliving amoebae from tap water and environmental water sources in Sivas. Türk Parazitol Derg 2012; 36: 198-203.
14. Coşkun KA, Özçelik S, Tutar L, Elaldı N, Tutar Y. Isolation and identification of free-living amoebae from tap water in Sivas, Turkey, BioMed Research International 2013; Article ID $675145, \quad 8 \quad$ pages. http://dx.doi.org/10.1155/2013/675145

15. Burak DM, Zeybek Z. Investigation of Legionella pneumophila and free living amoebas in the domestic hot water systems in İstanbul. Turk J Biol 2011; 35: 679-85.

16. Niyyati M, Lorenzo-Morales J, Rahimi F, Motevalli-Haghi A, Martin-Navarro CM, Shohreh F, Valladares B, Rezaeien M. Isolation and genotyping of potentially pathogenic Acanthamoeba strain from dust source in Iran. Tran.Roy Soc. Trop.Med. and Hyg. 2009; 103, 425-7.

17. Lawande RV. Recovery of soil amoebae from the air during the harmattan in Zaria, Nigeria, Ann Trop Med Parasitol 1983; 77: 45-9.

18. El Sibae MM. Detection of free-living amoeba(Acanthamoeba polyphagia) in the air conditioning systems. J Egypt Soc Parasitol 1993; 23: 687-90.

19. Chan LL, Mak JW, Low YT, Koh TT, Ithoi I, Mohammed SM. Isolatin and characterization of Acanthamoeba spp. from air-conditioners in Kuala Lumpur, Malaysia. Acta Tropica 2011; 117: 23-30.

20. Astorga B, Lorenzo-Morales J, Martín-Navarro $\mathrm{CM}$, Alarcón $\mathrm{V}$, Moreno J, González AC, Navarrete E, Piñero JE, Valladares B. Acanthamoeba belonging to T3, T4, and T11: genotypes isolated from air-conditioning units in Santiago, Chile. J Eukaryot Microbiol 2011; 58: 542-4. 